研究

\title{
ファイバーレーザを用いた金属粉末のレーザ結合に関する研究 ーレーザ照射部の温度測定一
}

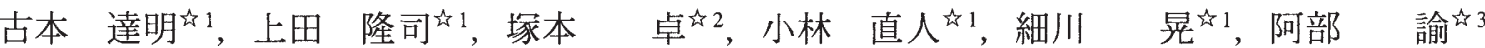 \\ 的1 金沢大学大学院，广920-1192 金沢市角間町。 \\ は2 コマツ， ₹ 107-8414 港区赤坂 2-3-6. \\ 衫松下電工侏), $=571-8686$ 門真市大字門真 1048.
}

\section{Study on Laser Consolidation of Metal Powder with Yb Fiber Laser - Temperature Measurement of the Laser Irradiation Spot-}

\author{
Tatsuaki Furumoto ${ }^{\text {tr } 1}$, Takashi Ueda ${ }^{\text {tr } 1}$, Takashi Tsukamoto ${ }^{\text {tr }}$, Naoto Kobayashi ${ }^{\text {th }}$,

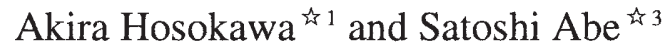 \\ ${ }^{\text {if } 1}$ Graduate School of Natural Science and Technology, Kanazawa University, Kakuma-machi, Kanazawa 920-1192, Japan. \\ ${ }^{2}$ Komatsu Ltd., 2-3-6 Akasaka, Minato-ku, Tokyo 107-8414, Japan. \\ ${ }^{3}$ Matsushita Electric Works, Ltd., 1048 Kadoma, Kadoma 571-8686, Japan.
}

Received April 17, 2007

\begin{abstract}
SYNOPSIS
The layered manufacturing technique is one of the most effective processes for the manufacture of prototypes, tools and functional end products. A variety of components, such as polymer, ceramic, paper and metal powder, has been applied to date for the achievement of manufacturing objectives. Selective Laser Sintering (SLS) and Melting (SLM), in particular, are two of the most versatile techniques, able to cover a wide range of materials. In this study, in-process monitoring of the processing temperature at laser irradiation spot is proposed by using two-color pyrometer, which has been developed by the authors. In order to investigate the consolidation characteristics of chromium molybdenum steel (SCM) based powders with a Yb fiber laser, the maximum temperature at the irradiation spot of a laser beam was measured under various experimental conditions. The influence of the laser power and diameter of laser beam on the temperature were evaluated. As a result, it was revealed that the maximum temperature during laser irradiation changed under the influence of laser power and particle size of powders. The temperature increased with the increase of laser power, and was greatly influenced by the particle size of the powders. The temperature after laser irradiation decreased rapidly to room temperature.
\end{abstract}

\section{KEY WORDS}

Yb fiber laser, laser consolidation, chromium molybdenum steel powder, two-color pyrometer, temperature

\section{1 緒言}

近年，消費者ニーズの多様化と共に製品ライフサイクルは ますます短くなり，製造メ一カは製品の開発から市場投入に 至るまでのプロセスを短縮化する様々な試みを行っている. 中でも，PCの普及と共に進化した 3 次元 CAD システムは, $\mathrm{CAM}, \mathrm{CAE}$ とのデータ共有を可能にし, 設計・開発期間の大幅 な工程短縮を実現するコンカレントエンジニアリングの実現 へと発展していった ${ }^{1)}$. 一方, 工程短縮の実現に奇与する要因 として, RPに代表される積層造形技術の進歩が挙げられる. 積層造形法とは，3 次元 CAD データを薄い層状のスライス データに変換し，同様に層状に堆積した樹脂や粉末に対して レーザ照射を行って照射部を選択固化し，得られた硬化層を 幾層にも積み上げながら 3 次元形状を作成する手法である2).
代表的な積層造形法としては, 紫外線を照射すると固化する 性質を有する感光性樹脂を用いた光造形法, インクジェット ノズルから加熱・溶融したワックスのような液滴を連続的に 滴下して堆積・固化されるインクジェット法, 金属やセラ ミックスの粉末にレーザ照射して加熱し，加熱粉末を相互に 結合して積層造形する粉末焼結法などに分類することができ る ${ }^{3)}$.これらは，3次元 CAD で作成したモデルを迅速に立体 表現できるため, モデル形状や意庍の検討に有効であり，応 力が付加されない状況においては部品の機能確認モデルとし ても利用されている.しかしながら，各造形法において使用 可能な材料に制限があり, 造形モデルの精度が機械加工と比 べて劣るため, 強度や耐久性の評価やモデルそのものを実部 品として製作することが困難である等の課題を有していた. 
これらの課題を解決する手法としてRM (Rapid Manufacturing) やRT (Rapid Tooling) と呼ばれる積層技術が注目されている ${ }^{4.5)}$. これは，実製品と同一品質の材料粉末を用いて製品を直接造 形するもので，近年ではエンドミル加工と組み合わせた複合 加工機も開発され，射出成形用金型の造形に適用されている6). 金型製作への本手法の適用は，梁リブ構造を有する形状の一 体造形が可能となり, 放電加工による後加工を必要としない ことから製作期間の短縮が期待される。しかしながら，金属 粉末を高密度で結合し，造形モデルの表面硬度も十分に持た せる必要があるなど課題も有している，これまでの研究で, 過多なエネルギ一投入ではボーリング現象が生じ，過小なエ ネルギー投入では十分な結合物が得られないため，良好な金 属粉末の結合物を得るには適切な投入エネルギ一の選択が必 要であることを示してきた7)。そこで本研究では，Ybファイ バーレーザを用いて金属粉末を結合するときの粉末表面温度 について，ファイバー導光型赤外線輻射温度計で測定し，表 面温度と金属粉末の結合特性との関係について調べたので， 以下に報告する。

\section{2 ファイバー導光型 2 色温度計}

2.1 温度計の測定原理

本実験で用いるファイバー導光型赤外線輻射温度計の概要 をFig.1に示す. 本温度計は, 赤外線導光ファイバー, 赤外線 検出素子および增幅回路から構成されている．測定対象物表 面から輻射された赤外線は，コア径が $380 \mu \mathrm{m}$ のカルコゲナイ ド光ファイバーで受光し，集光レンズを介して赤外線検出素 子に伝送される. カルコゲナイド光ファイバー (NSG) は，波 長が $1 \sim 7 \mu \mathrm{m}$ の赤外線を伝送することが可能である. 赤外線 検出素子は, InSb 素子の上に InAs 素子を積層した 2 色素子を 用いる. 前面のInAs 素子によって波長が $3 \mu \mathrm{m}$ 以下の赤外線を 受光し, InAs 素子を透過した $3 \mu \mathrm{m}$ を超える波長の赤外線は, 後面に配置した $\operatorname{lnSb}$ 素子で受光する. 各素子いずれも，赤外 線を照射すると起電力が生じる光起電力型素子であり，共に 応答速度が $1 \mu \mathrm{s}$ と速い ${ }^{8)}$. なお, InAs 素子は本実験に用いる ファイバーレーザの波長に対しても感度を有しており，素子

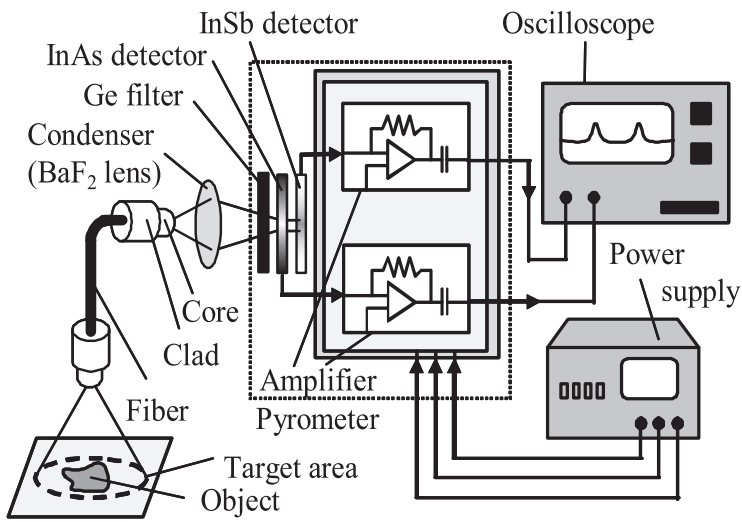

Fig.1 Fundamental structure of two-color pyrometer.
がレーザ光を検出すると正確な温度測定が行えない.そこで, InAs 素子の前面に Ge フィルターを配置し, 波長が $1.6 \mu \mathrm{m}$ 以下 の赤外線を全て遮光した. したがって, InAs素子は1.6〜 $3 \mu \mathrm{m}$ の波長を検出することとなる，検出された赤外線は，回路を 介して電気信号を増幅した後, オシロスコープで表示させて 出力を記録した，得られた出力の温度への換算は，両素子か らの出力比を取り別途測定した校正曲線を用いて行う．両素 子からの出力比を取ることで, 測定対象物表面からの赤外線 輻射率の影響を抑えることができる9?.

2.2 温度計の校正実験

温度計は，測定する温度に応じて熱電対を用いる方法と試 料融点を用いる方法の 2 種類で校正実験を行った。熱電対を 用いる校正方法の概略をFig.2に示す. 校正にはアルミナを試 料として用いた．まず, アルミナ裏面にクロメルーアルメル 熱電対を貼付し，周辺にニクロム線を配置して全体を絶縁体 で覆う。そして, 試料全体の温度が均一となるようにニクロ ム線を加熱し, 試料表面から輻射される赤外線をカルコゲナ イド光ファイバーで受光する.このとき, 試料裏面の温度を 熱電対で同時に测定することで，熱電対から求まる絶対温度 と2色素子からの出力との関係を知ることができる. なお, 輻 射赤外線は, 2色素子の検出前にチョッパーを用いてパルス出 力に変換している.

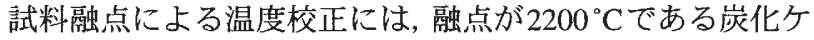
个素と ${ }^{10)}$, 融点が $1510^{\circ} \mathrm{C}$ である冷間圧延鋼板を用いた ${ }^{11)}$. そ れぞれ, 条件を変えながら試料表面にレーザ光(日本電気侏)製 : SL117C)を照射し, 試料表面が溶融する最小のエネルギ一条 件のときの輻射赤外線を 2 色素子で测定して, それらの出力 比から融点との関係を求めた. Fig. 3 は, 溶融前後における炭 化ケ个素の表面をSEM (日本電子(株)製: JSM-6390LVU) で観察 した結果である. 溶融前における炭化ケイ素の表面は, Fig.3(a) に示すように照射痕のみが観察できるのに対して, 溶融後の 表面は, Fig.3 (b)に示すように炭化ケイ素表面に再凝固層が存 在している. 本実験では，このときの各素子からの出力を測 定して，その出力比を融点とした.

Fig.4は, 各校正実験の結果と計算によって求めた理論曲線 との関係を示す。理論曲線は, 検出素子, 伝送用ファイバ一,

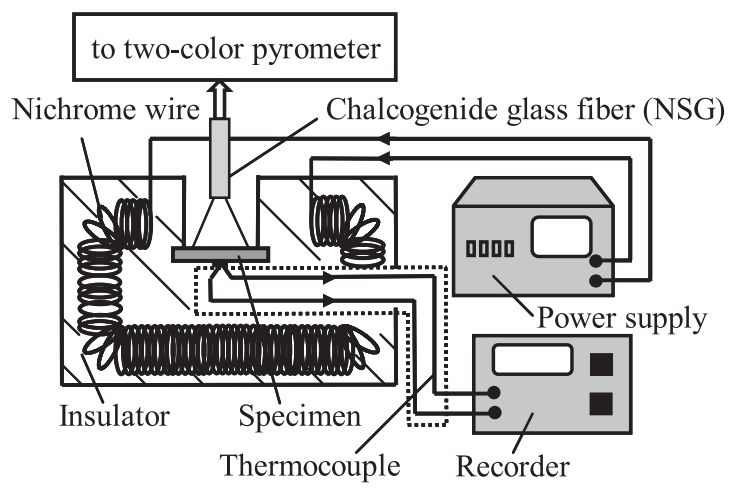

Fig.2 Schematic illustration for calibration of pyrometer 


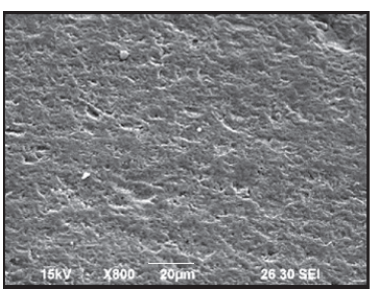

$50 \mu \mathrm{m}$

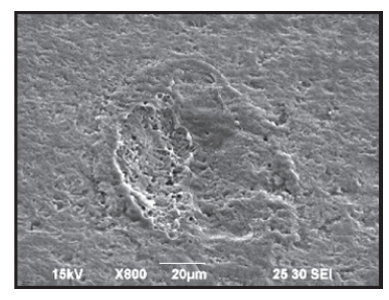

$50 \mu \mathrm{m}$
Fig.3 SEM image of SiC surface.

(a) Before irradiated, (b) After irradiated

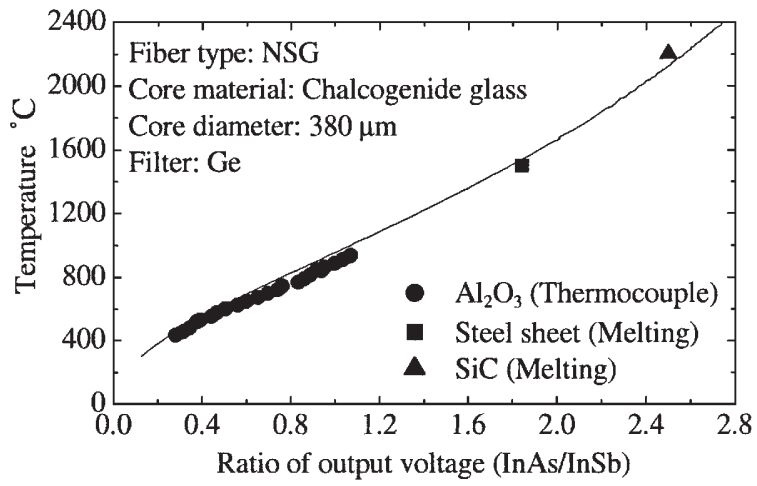

Fig.4 Calibration curve.

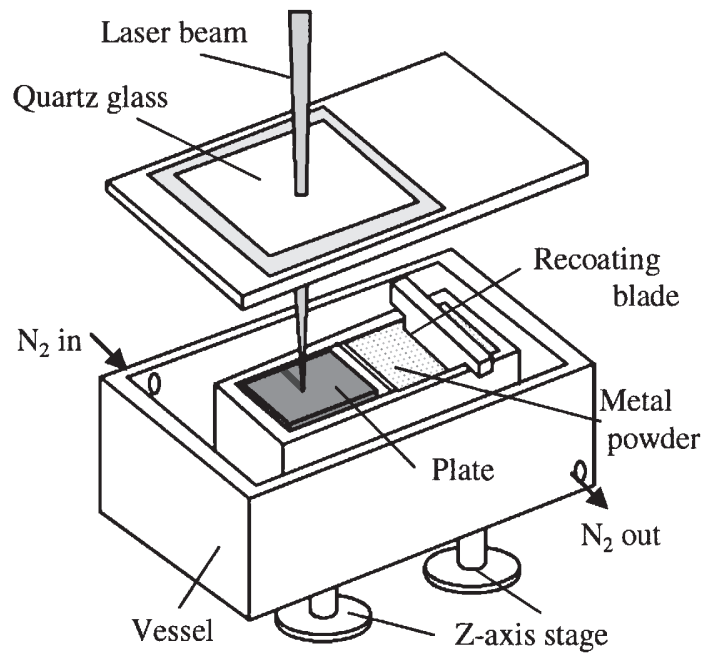

Fig.5 Schematic illustration of experimental arrangement.

$\mathrm{Ge}$ フィルターなどの各波長における相対感度を用いて計算し たものである.グラフから, 熱電対を用いて得られた結果, 試 料融点から得られた結果が，いずれも理論值と良く一致して いることがわかる．したがって，本温度計を用いた測定結果 はグラフ中の理論曲線を用いて行うこととした.

\section{3 実験方法}

3.1 実験装置

金属粉末のレーザ結合装置の概要をFig.5に, 実験に用いる
Table 1 Specification of $\mathrm{Yb}$ fiber laser.

\begin{tabular}{lll}
\hline Laser type & & Yb fiber $(\mathrm{CW})$ \\
Beam diameter & $\phi$ & $45 \mu \mathrm{m}$ \\
Wavelength & $\lambda$ & $1070 \mathrm{~nm}$ \\
Maximum power & $P$ & $40 \mathrm{~W}$ \\
Scanning speed & $F$ & $1-3000 \mathrm{~mm} / \mathrm{s}$ \\
\hline
\end{tabular}

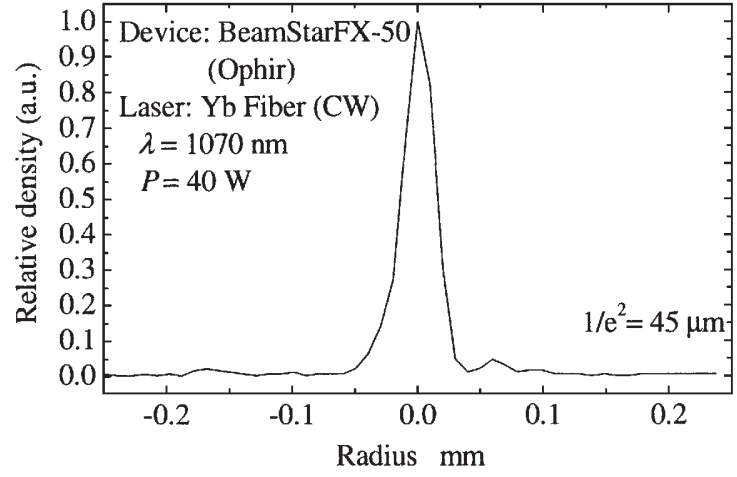

Fig.6 Profile of laser beam at focus spot.

レーザの仕様を Table 1 に示す. 装置は, 波長が $1070 \mathrm{~nm}$ の連 続発振 Ybファイバーレーザ(SUNX株製: LP-F10) と金属粉末 の結合ユニットで構成されている，結合ユニットには，粉末 の堆積厚さを調節するためのブレードが取り付けられ，X-Y ステージに固定した結合用プレートの表面に, 任意の高さで 粉末を堆積させることができる. 照射するレーザパワーは $P=$ $10 \sim 40 \mathrm{~W}$ で変化させ，ガルバノメータミラーを介して伝送 されたレーザ光が, 堆積粉末表面に焦点を結ぶように調整し た.なお，レーザ照射時は粉末表面の酸化を防ぐため, ユニッ ト内部を窒素ガスで充填した。

Fig.6は,ビームプロファイラ(OPHIR製: BeamStarFX-50)を 用いて, $P=40 \mathrm{~W}$ のさにおける焦点位置のビームプロファ イルを測定した結果である.ガルバノメータミラーを介して 集光しているため, 集光レンズを用いたビーム径より大きく なっているが, ビーム形状が $\mathrm{TEM}_{00}$ のガウシアン形状を呈し

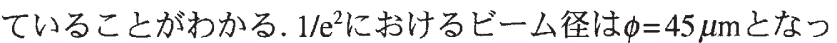
た.

\section{2 実験用粉末}

使用する金属粉末は，粉末焼結型積層造形で一般的に用い られる鉄系粉末, 銅系粉末, ニッケル系粉末などから構成さ れる混合粉末であり, その平均粒径は $17 \mu \mathrm{m}, 25 \mu \mathrm{m}$ の 2 種類 を用いた. また, プレート表面に粉末を堆積させるとき上面 からの加圧は行わず, 粉末の自重のみで堆積させた状態を標 準状態とした。このときのかさ密度を測定したところ，平均 粒径が $25 \mu \mathrm{m}$ のときは $4290 \mathrm{~kg} / \mathrm{m}^{3}, 17 \mu \mathrm{m}$ のときは $4180 \mathrm{~kg} / \mathrm{m}^{3}$ と, それぞれ真密度と比較して $50 \%$ 程度となった ${ }^{12)}$.

3.3 実験方法

レーザ照射時の温度測定部拡大図を Fig.7に，実験条件を Table 2 に示す. ステージ上に取り付けた冷間圧延鋼 $\left(t_{\mathrm{p}}=3.2\right.$ 


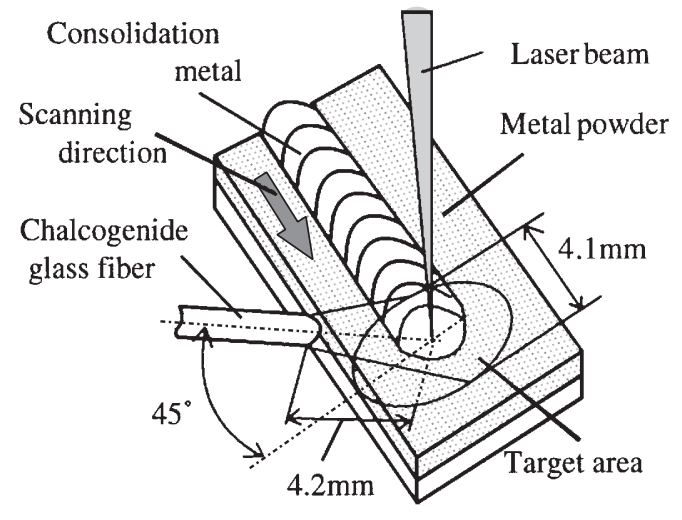

Fig.7 Enlargement of laser irradiation spot.

Table 2 Experimental conditions.

\begin{tabular}{llc}
\hline Laser power & $P$ & $10-40 \mathrm{~W}$ \\
Scanning speed & $F$ & $88-180 \mathrm{~mm} / \mathrm{s}$ \\
Layer thickness & $t$ & $50 \mu \mathrm{m}$ \\
Particle size & $d$ & $17,25 \mu \mathrm{m}$ \\
\hline
\end{tabular}

$\mathrm{mm})$ に, リコーティングブレードを用いて金属粉末の厚みが $t=50 \mu \mathrm{m}$ で均一となるように堆積させ，レーザ光をライン状 に走査したときの温度を測定する．測定に用いるカルコゲナ イドファイバーは，走査するレーザ光がファイバーの受光工 リアに対して中心を通るように設置し，受光エリア内部を レーザ光が通過するとき, 加熱された粉末表面から輻射され る赤外線を受光する. このとき, ファイバーは堆積した粉末 表面との角度が 45 度で, ファイバー先端とレーザ照射位置と の直線距離が $4.2 \mathrm{~mm}$ の位置に固定した. 使用するファイバー の開口数は $N A=0.4$ であり, 輻射赤外線の最大受光角は $23.6^{\circ}$ となることから ${ }^{13)}$, 受光エリアの幅は $4.1 \mathrm{~mm}$ となる. したがっ て, レーザ照射部とファイバー先端との距離が $4.2 \mathrm{~mm}$ の場 合, レーザ光がファイバー先端を通過する長さ $4.1 \mathrm{~mm}$ におけ る温度変化を測定することとなる。

まず，レーザ照射条件が照射部温度に与える影響を調べる ため, Table 2に示すようにレーザ光の照射パワーを変えたと きの温度変化について調べた。 そして，各条件で得られた結 合金属をSEM (日本電子怢製: JSM-6390LVU)で観察して比較 した。 また，粉末粒径が照射部温度に与える影響を調べるた め, 粒径の異なる粉末で同様の実験を行った。ささらに,レー ザビーム形状の違いによる粉末の結合特性を調べるため, 焦 点位置とデフォーカス量が $D_{\mathrm{f}}=8 \mathrm{~mm}$ の位置でレーザ照射し て，それぞれの照射部温度や結合状態を調べた。

4.1 温度計出力波形例

\section{4 実験結果および考察}

Fig.8 は, レーザ光の走查速度が $F=180 \mathrm{~mm} / \mathrm{s}$ のときにおけ る各検出素子からの出力波形および，各素子における時間毎 の出力から比を求めて温度に換算した結果である. ファイ

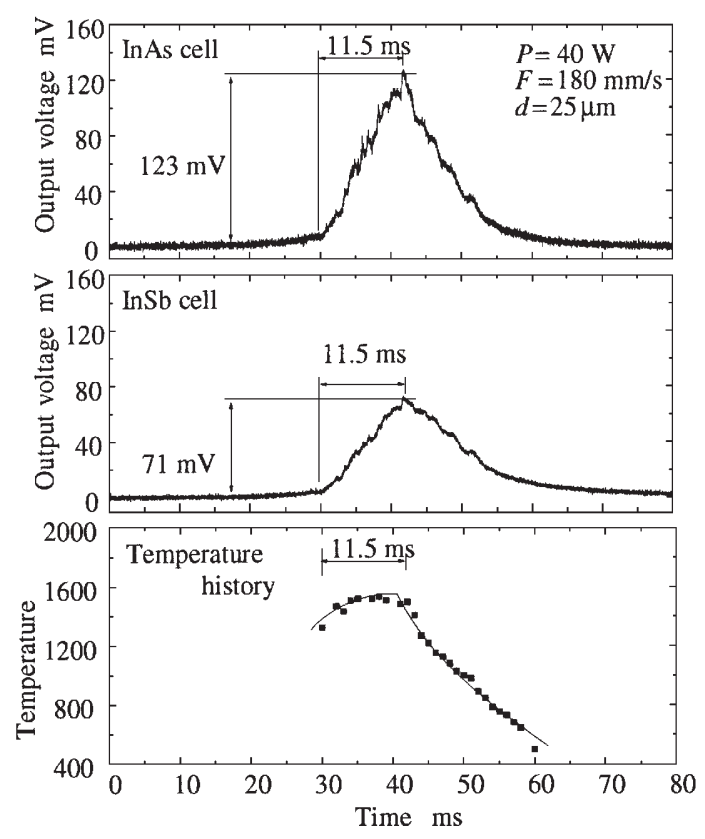

Fig.8 Recorded output waves of pyrometer.

バー先端を通過するレーザ光の速度 $180 \mathrm{~mm} / \mathrm{s}$ とファイバーの 受光エリアの幅 $4.1 \mathrm{~mm}$ との関係から, 受光エリア内をレーザ 光が通過する時間は $22.8 \mathrm{~ms}$ となる.

Fig.8に示すように, 両素子からの出力はいずれもレーザ光 がファイバーの受光エリアに進入した直後から確認でき，そ れから $11.5 \mathrm{~ms}$ 後に出力が最大となり, その後急速に出力が低 下している. 受光エリア内部のレーザ走査時間との関係から, 走查レーザ光が受光エリアの中心付近に到達したとき, 各素 子からの出力が最大となることがわかる.このとき, $\mathrm{Ge}>ィ$ ルターを用いて $1.6 \mu \mathrm{m}$ 以下の波長を遮光しているため, 走查 したレーザ光の反射成分は検出されていない.

温度に換算した結果においても, 各素子からの出力が最大 となるまで次第に温度が上昇し, 中心を通過した直後から急 速に減少している.この波形例の場合, レーザ光が中心付近 に到達したとき約 $1600^{\circ} \mathrm{C}$ であるが，わずか $20 \mathrm{~ms}$ 経過すると $400^{\circ} \mathrm{C}$ 近くまで減少している。これは，実験に用いる粉末の 熱容量が小さく, レーザ光の走査直後から急速に温度が低下 したためと考えられる. 得られた結果から,レーザ光照射に 対して本温度計を用いて十分測定できることがわかる. 本実 験では, 温度計の各素子の出力においてその最大值の比を取 り，温度に換算して評価することとする.

4.2 レーザ照射条件と照射部温度との関係

Fig. 9 は, レーザ光の走查速度が $F=88 \mathrm{~mm} / \mathrm{s}$, 粉末粒径が $d=25,17 \mu \mathrm{m}$ のときにおけるレーザパワーと照射部温度との関 係を示している.いずれもサンドブラスト処理した冷間圧延 鋼上に堆積した粉末にレーザ照射実験を行った結果である. 図に示すように，いずれの粒径においてもレーザパワーが大 きくなるにつれて照射部温度が高くなっている. 粉末粒径が $d=17 \mu \mathrm{m}$ の場合, レーザパワーが $P=10 \mathrm{~W}$ のとき約 $1500^{\circ} \mathrm{C}$ で 


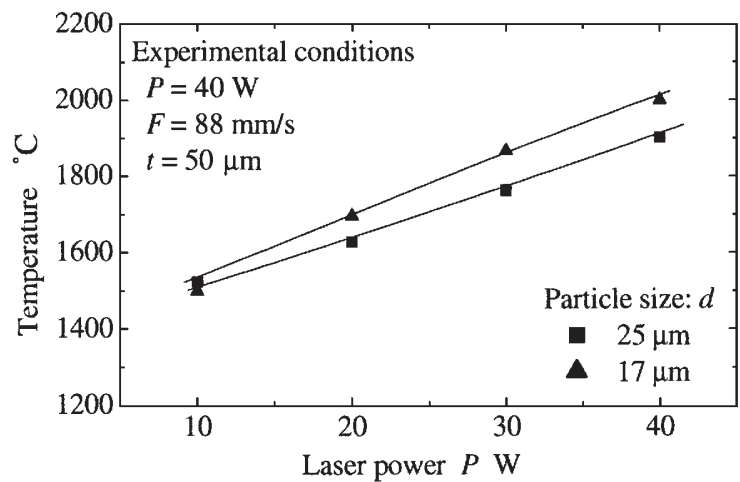

Fig.9 Influence of particle size on temperature.

あった照射部温度は, $P=40 \mathrm{~W}$ になると約 $2000^{\circ} \mathrm{C}$ まで上昇し ている．これは，粉末に投入される単位面積あたりのエネル ギー量に依存していると考えられ,レーザパワーが大きくなる につれて投入エネルギーが増加したためである，一方，粒径 の違いについて比較すると, 粒径が $d=25 \mu \mathrm{m}$ の照射部温度が $d=17 \mu \mathrm{m}$ の場合より低く, レーザパワーが $P=40 \mathrm{~W}$ のとき約 $100^{\circ} \mathrm{C}$ の違いがある。これは，粉末の熱伝導率や熱容量の違 いによるものと考えられる.これまでの研究で, 粉末粒径が 小さくなるにつれて熱伝導率や熱容量が小さくなることがわ かっており ${ }^{12)}$ ，粒径が小さい方がレーザ照射で生じた熱が拡 散されにくく，照射部温度が上昇したためと考えられる。

Fig.10は, Fig.9で得られた結合物をSEM観察した結果であ る. いずれも，レーザ光を図中に示す方向に $F=88 \mathrm{~mm} / \mathrm{s}$ で走 査し，サンドブラスト処理したプレート上に結合したときの 結果である. 粉末粒径が $d=17 \mu \mathrm{m}$ のとき, レーザパワーが $P=$ 10 Wでは結合物がボール状となってプレート表面に接合して いるのに対して，P=20 W 超えると結合物がライン状に連 なっている様子がわかる. 一方, 粉末粒径が $d=25 \mu \mathrm{m}$ のとき, レーザパワーが $P=20 \mathrm{~W}$ までは結合物がボール状となってい るが, $P=30 \mathrm{~W}$ を超えるとライン状に連なっている.

このように結合の様子が異なるのは，レーザ照射に起因し た粉末およびプレート表面の溶融状態に違いが生じたためと 考えられる、プレートに粉末を溶融・結合するとき，レーザ 照射による熱でプレート表面も溶融され，凝固の過程でそれら が合金化されながら接合する機序となる.Fig.9で示したよう に, 照射部温度は粉末の熱伝導率や熱容量の違いに起因して, 粉末粒径が小さい方が高くなった. すなわち, 粉末粒径が $d=$ $17 \mu \mathrm{m}$ 方が, 低いレーザパワーでライン状の構造物を得る十 分なエネルギー供給がなされたといえる，一方，粉末粒径が $d=25 \mu \mathrm{m}$ の場合には, レーザパワーが $P=20 \mathrm{~W}$ の条件では十 分に加熱・溶融されず，ライン状の結合物を得るには，より 多くのレーザパワーが必要になったものと考えられる.

これらの結果より,レーザ照射時の粉末表面の温度によって， 粉末の溶融・結合形態に違いが見られることが明らかとなつ た. 粉末の主成分である鉄系材料の融点は $1490^{\circ} \mathrm{C}$ である ${ }^{111}$. したがって，レーザ照射部が融点近傍の温度に到達すると粉

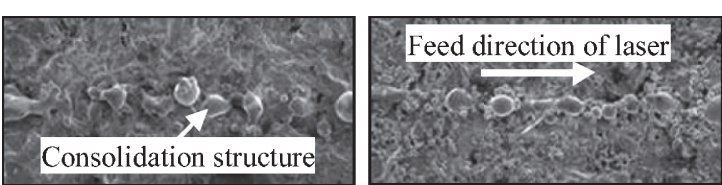

$P=10 \mathrm{~W}$

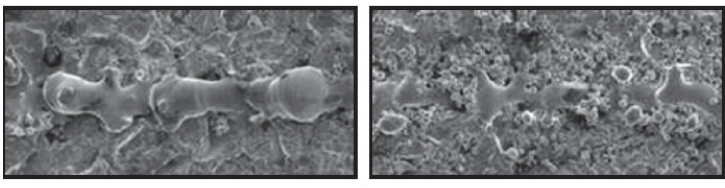

$P=20 \mathrm{~W}$

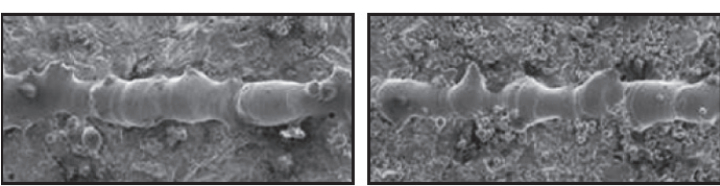

$P=30 \mathrm{~W}$
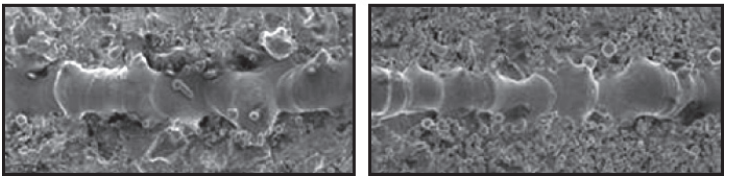

$P=40 \mathrm{~W}$

$\overline{200 \mu \mathrm{m}}$

Fig.10 SEM images of the consolidation metal. (a) $d=17 \mu \mathrm{m}$, (b) $d=25 \mu \mathrm{m}$

末の溶融がはじまり，このとき溶融物はプレート上にボール 状で結合する状態となる，そして，さらに加熱されると溶融 物は次第にライン状に結合する状態となることから，この範 囲において溶融粉末をライン状に結合させるための最適な温 度が存在することとなる。本実験の範囲において，レーザ照 射による投入エネルギーが不十分で結合物がボール状となつ たのは，いずれも照射部温度が $1700^{\circ} \mathrm{C}$ 以下であることから， 照射部温度を $1700^{\circ} \mathrm{C}$ 以上にすことによって溶融粉末をライ ン状に結合できることとなる，また，溶融粉末の結合状態と 照射部温度に相関が認められることから, 照射部温度を監視 することによって各粉末の結合状態を把握できる可能性があ るといえる。

4.3 レーザビーム形状が結合特性に与える影響 4.3.1 エネルギー分布

Fig.11 は, 焦点位置とデフォーカスが $D_{\mathrm{f}}=8 \mathrm{~mm}$ のときの ビームプロファイルを比較した結果，Fig.12 は焦点位置にお けるピーク出力を 1 とし, ピーク出力とレーザ光のスポット 径との関係を示した結果である. Fig.11に示すように, レー ザ光はともにガウシアン形状を呈している，また，デフォー カスが $D_{\mathrm{f}}=8 \mathrm{~mm}$ のときビーム径は $\phi=278 \mu \mathrm{m}$ となり, 焦点位 置におけるスポット径と比較して約6倍大きくなった. 一方, レーザ光のピーク出力は, Fig.12に見るようにスポット径が 大きくなるにつれて急激に小さくなり，デフォーカスが $D_{\mathrm{f}}=$ $8 \mathrm{~mm}$ のときにおけるピーク出力は, 焦点位置のそれと比較し て約 $1 / 12$ となった. 

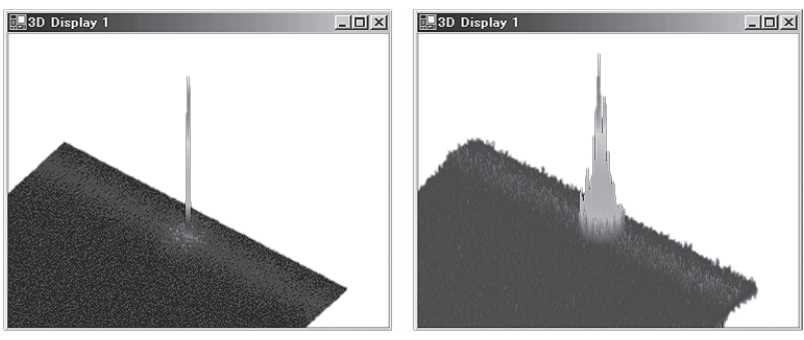

Fig.11 Profile of irradiated laser beam. (a) Focus $(\phi=45 \mu \mathrm{m})$, (b) Defocus $(\phi=278 \mu \mathrm{m})$

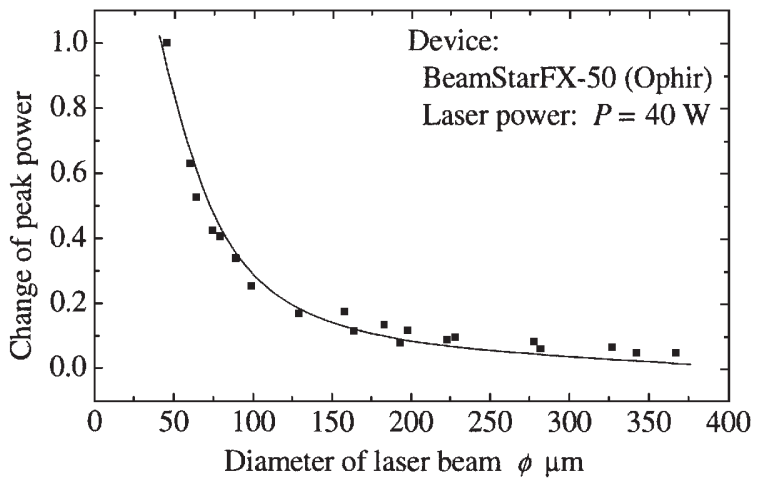

Fig.12 Relation between diameter of laser beam and peak power.

\section{3 .2 照射部温度}

Fig.13 は，粉末粒径が $d=25 \mu \mathrm{m}$ のとき，ビ一ム形状の違い による照射部温度を測定した結果である．比較のため，サン ドブラスト処理した冷間圧延鋼表面にレーザ照射したときに 得られた測定結果も併せて示す. 図からわかるように, 各条件 においてレーザパワーが大きくなるにつれて照射部温度は高 くなっている.粉末上にデフォーカスでレーザ照射した場合， $P=10 \mathrm{~W}$ のと約 $1500^{\circ} \mathrm{C}$ であった照射部温度は, $P=40 \mathrm{~W}$ なると $1850^{\circ} \mathrm{C}$ ま昇している. また，スポット径の違いに よる温度を比較すると, デフォーカス位置における照射部温 度が全体的に低く,レーザパワーが $P=40 \mathrm{~W}$ のき約 $50^{\circ} \mathrm{C}$ の 違いが見られる。一方，プレート上にレーザ照射したときの 温度は，粉末上の温度と比較して全体的に低くなっている. また，ビーム形状の違いによる温度差が大きく，デフォーカ スで照射したとき最大で $200^{\circ} \mathrm{C}$ 低くなった.

\subsection{3 デフォーカスの影響}

Fig.14 は，レーザパワーが $P=40 \mathrm{~W}$ のとき，各条件で得ら れた結合物をSEM観察した結果である. 図に見るように，焦 点位置では結合物がライン状に凝固しているのに対して，デ フォーカス位置では結合物がボール状に点在している．この ときの照射部温度は, Fig.13で示したように焦点位置で 1900 ${ }^{\circ} \mathrm{C}$, デフォーカス位置で $1850^{\circ} \mathrm{C}$ である. すなわち, 焦点位置 におけるレーザ照射ではライン状に結合した温度域でもボー ル状に結合していることとなる．このような結合状態の違い は，レーザ照射による投入エネルギーと粉末の溶融領域に

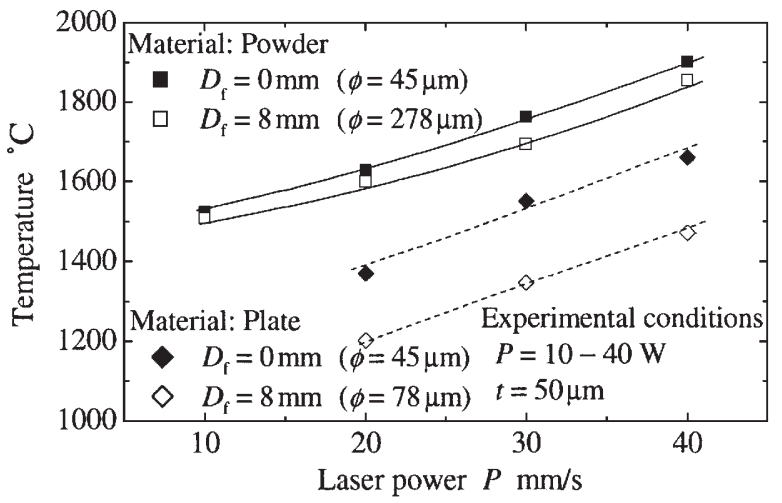

Fig.13 Influence of diameter of laser beam on temperature.
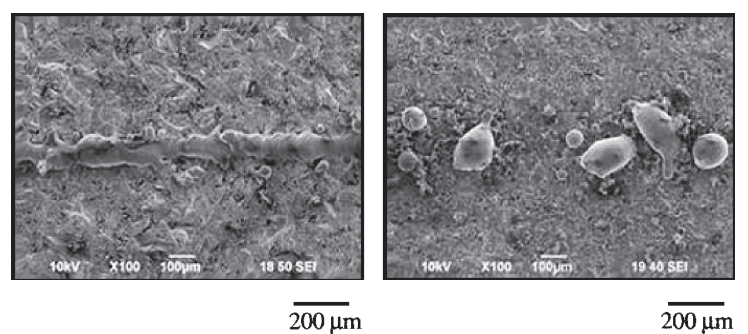

Fig.14 SEM image of the consolidation metal $(P=40 \mathrm{~W})$. (a) $D_{\mathrm{f}}=0 \mathrm{~mm}$ (focus), (b) $D_{\mathrm{f}}=8 \mathrm{~mm}$

よって生じると考えられる. デフォーカスでレーザ照射する ことで粉末の溶融領域が大きくなり，より多くの溶融粉末が 凝集・結合したため, 照射部温度が高温になっても結合物が ボール状に点在したものと考えられる. また，プレート上に レーザ照射したときの温度はスポット径の違いによって大き く異なっているが, 粉末上にレーザ照射したときの温度はス ポット径の違いほど変化が無く, スポット径が照射部温度に 与える影響は小さいといえる. これは, レーザ光をデフォー カスで照射するとエネルギー密度が低くなるのに対して, 照 射するレーザ光がガウシアン形状を呈しており，また，粉末 の熱伝導率が小さいため, レーザ照射部中心付近の温度が上 昇したためと考えられる。

\subsection{4レーザパワーの影響}

レーザパワーによる違いを比較すると, 焦点位置における レーザ照射では, 全条件においてプレート表面に溶融物が接 合していたのに対して，デフォーカス位置によるレーザ照射 では, $P=20 \mathrm{~W}$ 以下のとき, 溶融物がプレート上に接合しな かった．このようなレーザスポット径の違いによる接合状態 の変化は, レーザ光のピーク出力に大きく寄与していると考 えられる、レーザ光をデフォーカスで照射することでピーク 出力が小さくなり, バルク材であるプレートの熱伝導率が粉 末と比較して大きいため, プレート表面の温度が十分に上が らず溶融物が接合されなかったためと考えられる.

これらの結果から、レーザ光のスポット径が照射部温度に 与える影響は小さいが, 溶融物の結合状態はスポット径に 
よって大きく異なることがわかった. したがって，スポット 径を変化させて溶融粉末を同様の状態で結合させるためには, レーザパワーやレーザスポット径などの条件選定を慎重に行 う必要があるといえる．このとき，レーザ照射部の温度とと もにレーザ光のビーム形状に注目することによって，溶融粉 末の結合状態を把握できると考えられる.

\section{5 結 言}

本研究では，金属粉末を高精度にレーザ結合しながら金型 構造物を造形する RT 技術を確立するための基礎的研究とし て, Ybファイバーレーザを用いて金属粉末をレーザ結合する ときの表面温度について, ファイバ一導光型赤外線輻射温度 計で測定する手法を提案するとともに，同手法を用いてレー ザ照射条件と金属粉末の結合特性との関係について調べた。 以下に, 得られた結果を要約する.

（1）金属粉末表面にレーザ光を走査させると,レーザ光が近づ くにつれて急激に温度が上昇し照射部中心付近が最高温度 となる．また，レーザ光が通過して $20 \mathrm{~ms}$ 経過すると，照 射部温度が $400^{\circ} \mathrm{C}$ 以下に低下する。

(2) レーザ照射によって得られた結合物は,レーザパワーや粉 末粒径の違いによってプレート表面に対する結合状態が異 なる．レーザ光の照射部温度が $1700^{\circ} \mathrm{C}$ を超えると結合物 がライン状に接合され，それ以下では結合物がボール状に 点在する.

(3) レーザスポット径の違いによる照射部温度の変化は小さ く,プレートに対する溶融物の結合はレーザ光のピーク出 力に大きく影響を受ける。

(4) 粉末の結合状態とレーザ照射部温度に相関が認められ, レーザ照射部の温度を監視することで,粉末の結合状態が 把握できる可能性がある。

\section{謝辞}

本研究は，地域新生コンソーシアム研究開発事業「金属光 造形と成形技術の高度化による企業連携グリッドモデル構築」 (H18-19) で得られた成果である.

\section{文献}

1) K. Hitomi: "Introduction to Manufacturing Systems Engineering, Second Edition", Kyoritsu Shuppan Co., Ltd., (2000) 201.

2) T. Nakagawa and Y. Marutani: "Sekisou Zoukei System", Kogyo Chosakai Publishing Co., Ltd., (1996)4.

3) Y. Marutani, et al.: "Sekisou Zoukei Gijutu Siryosyu", The OPTRONICS Co , Ltd., (2002) 11.

4) K. Maekawa: "Rapid Prototyping Using Laminated Manufacturing with Laser Sintering", J. Jpn. Soc. Prec. Eng., 70(2004)167-170.

5) M. Imamura: "Recent Trend about the Metal Rapid Prototyping Using Powder", J. Jpn. Soc. Powder Powder Metallurgy, 48 (2001)415-421

6) S. Abe, Y. Higashi, et al.: "Development of milling-combined laser metal sintering method", J. Jpn. Soc. Prec. Eng., 73(2007) 912-916.

7) T. Furumoto, T. Ueda, et al.: "Study on the Sintering Characteristics of the Metal Powder for Rapid Tooling with $\mathrm{Yb}$ fiber laser", Jpn. Soc. Prec. Eng. Autumn Meeting, (2007)495496.

8) A. Hosokawa, et al.: "Temperature of Tool Frank in Intermittent Cutting (1st report)", J. Jpn. Soc. Prec. Eng., 66(2000) 17861791.

9) M. Sato, T. Ueda, et al.: "Measurement of Tool Face Temperature in Orthogonal Diamond Cutting", J. Jpn. Soc. Prec. Eng., 64 (1998) 892-896

10) S. Iida and K. Ohno: "Butsuri Teisuuhyo", Asakura Publishing Co., Ltd., (1969) 199.

11) "Dennetsu Kougaku Siryou, the 3rd edition", Jpn. Soc. Mech. Eng., (1975) 296

12) T. Furumoto, Takashi Ueda, et al.: "Study on the Measurement of Physical Property in the Metal Powder for Rapid Prototyping", J. Jpn. Soc. Prec. Eng., 73(2007)558-562.

13) Y. Suematsu, et al.: "Hikari Fiber Tsuushin Nyumon", Ohmsha, Ltd., (1989) 20 . 